\title{
Double-orifice (DO) repair of Ebstein tricuspid valve: Just DO it!
}

\author{
Ronald K. Woods, MD, PhD, and Viktor Hraska, MD, PhD
}

\author{
From the Division of Pediatric Cardiothoracic Surgery, Department of Surgery, Medical College of Wisconsin, \\ Milwaukee, Wis; and Herma Heart Institute, Children's Hospital of Wisconsin, Milwaukee, Wis. \\ Disclosures: Authors have nothing to disclose with regard to commercial support. \\ Received for publication Oct 31, 2018; accepted for publication Oct 31, 2018. \\ Address for reprints: Ronald K. Woods, MD, PhD, Division of Pediatric Cardiothoracic Surgery, Department of \\ Surgery, Medical College of Wisconsin, Children's Hospital of Wisconsin, 9000 W Wisconsin Ave, MS B 730, \\ Milwaukee, WI 53226 (E-mail: rwoods@chw.org). \\ J Thorac Cardiovasc Surg 2019;157:e51 \\ $0022-5223 / \$ 36.00$ \\ Copyright (c) 2018 by The American Association for Thoracic Surgery \\ https://doi.org/10.1016/j.jtcvs.2018.10.121
}

In their case report in this issue of the Journal, Delmo Walter and colleagues ${ }^{1}$ describe their double-orifice (DO) repair of an Ebstein tricuspid valve. They provide a very clear description of the technique, along with beautiful illustrations. Importantly, valve function remains very good at 30-year follow-up in the now 71-year-old patient. Although lacking in any scientific proof, this case at least demonstrates the possibility of excellent durability. Moreover, it is always encouraging, and in some respects entertaining, to read a case report with 30 years of follow-up.

Not having used this technique personally, our comments are more speculative. The technique appears to be relatively straightforward and possibly applicable to any type of valve that would otherwise be amenable to some other form of repair. Even if the intraoperative result is unsatisfactory, it is easily undone without compromising other methods of repair. For the very poorly delaminated anterior leaflet, it should be possible to detach the anterior leaflet and conduct a thorough delamination, as is done in the cone repair, then simply reattach the leaflet and proceed with the DO repair. Likewise, if the other 3 leaflets are not too apically displaced, delamination of those leaflets might contribute to competence and require less "tight" DO sutures. The completely apposing, or "tight," DO sutures clearly distort the anterior atrioventricular groove, which theoretically could impair flow in the right coronary artery. Use of polytetrafluoroethylene strips along the respective sections of the anterior and septal annulus to lengthen the apposition and alter the distribution of tension might permit less tight DO sutures and less distortion without compromising competence. Although the patient in the report of Delmo

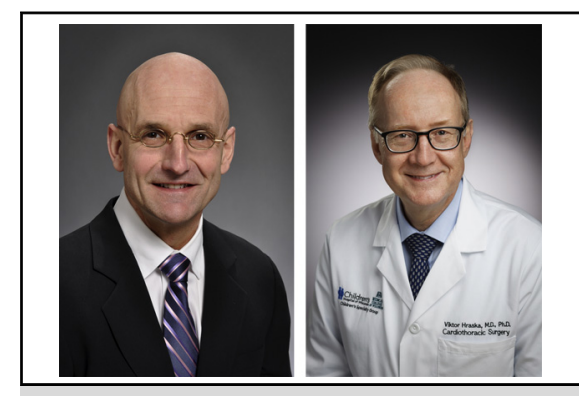

Ronald K. Woods, MD, PhD (left), and Viktor Hraska, $\mathrm{MD}, \mathrm{PhD}$ (right)

\section{Central Message}

The double-orifice technique appears to be a relatively straightforward repair that may offer excellent durability.

See Article page e47.

and Walter and colleagues ${ }^{1}$ fared well, postrepair coronary imaging in a series of patients would be informative.

In their 2015 report in the Journal of a cohort of 68 patients with Ebstein malformation, the same group described use of the DO repair in approximately 9 patients. $^{2}$ In their discussion section of that article, they state, "Based on the satisfactory outcomes in this group, we have preferred this technique since 2002 in almost all types of Ebstein's anomaly." Although the entire cohort included a certain number of pediatric patients (percentage not defined), pediatric-specific outcomes were not reported. We find no compelling theoretic grounds for proscribing this technique on the basis of age. If a neonatal or infant valve is amenable to repair, there should be sufficient cross-sectional area in most cases to permit the DO repair. So the next time we consider a patient with Ebstein malformation, perhaps we should just DO it!

\section{References}

1. Delmo Walter EM, del Maria Javier MF, Hetzer R. The first known use of the double-orifice valve technique for Ebstein anomaly, performed 30 years ago. J Thorac Cardiovasc Surg. 2019;157:e47-9.

2. Hetzer R, Hacke P, Javier M, Miera O, Schmitt K, Weng Y, et al. The long-term impact of various techniques for tricuspid repair in Ebstein's anomaly. J Thorac Cardiovasc Surg. 2015;150:1212-9. 